\title{
Emended Description of the Genus Agromyces and Description of Agromyces cerinus subsp. cerinus sp. nov., subsp. nov., Agromyces cerinus subsp. nitratus sp. nov., subsp. nov., Agromyces fucosus subsp. fucosus sp. nov., subsp. nov., and Agromyces fucosus subsp. hippuratus sp. nov., subsp. nov.
}

\author{
H. I. ZGURSKAYA, ${ }^{1}$ L. I. EVTUSHENKO, ${ }^{1 *}$ V. N. AKIMOV, ${ }^{1}$ H. V. VOYEVODA, ${ }^{1}$ \\ T. G. DOBROVOLSKAYA, ${ }^{2}$ L. V. LYSAK, ${ }^{2}$ AND L. V. KALAKOUTSKII ${ }^{1}$ \\ All-Russian Collection of Microorganisms, Institute of Biochemistry and Physiology of Microorganisms, \\ Russian Academy of Sciences, Pushchino, Moscow Region $142292,{ }^{1}$ and Department \\ of Soil Sciences, Moscow State University, Moscow 119789, ${ }^{2}$ Russia
}

\begin{abstract}
Fourteen soil-inhabiting, fragmenting actinomycetes with diaminobutyric acid in their cell walls and MK-12 as their major menaquinone were characterized and assigned to two new Agromyces species; these organisms were further subdivided into four subspecies on the basis of numerical data, cell wall sugar compositions, and levels of DNA relatedness. The key characteristics which differentiated between the new species and subspecies of the genus Agromyces and Agromyces ramosus included the presence of tyvelose or fucose in the cell walls; some physiological properties, including catalase and oxidase activities; growth on media supplemented with inorganic nitrogen; reduction of nitrate; and hydrolysis of hippurate. The data which became available when we studied more strains of Agromyces species and subspecies suggested that the genus description should be emended. We suggest that the following characteristics should be included in the genus description: catalase and oxidase activities are variable; the majority of strains grow on inorganic media; as a rule, galactose and rhamnose are present in the cell walls; some strains contain glucose, fucose, tyvelose, mannose, ribose, and/or xylose as the major cell wall sugar(s); iso and anteiso types of fatty acids predominate (94\%); and the G+C contents of the DNAs are 70 to $72 \mathrm{~mol} \%$, as determined by the thermal denaturation method. The type strains of the new species and subspecies are as follows: Agromyces cerinus subsp. cerinus VKM Ac-1340, Agromyces cerinus subsp. nitratus VKM Ac-1351, Agromyces fucosus subsp. fucosus VKM Ac-1345, and Agromyces fucosus subsp. hippuratus VKM Ac-1352.
\end{abstract}

The group of actinomycetes and coryneform bacteria which have two molecules of diaminobutyric acid in their peptidoglycans is represented by members of the genera Agromyces (10) and Clavibacter (5) and by individual strains of coryneform bacteria whose taxonomic positions are unclear ("Corynebacterium spp.") (5).

Soil actinomycetes belonging to the genus Agromyces Gledhill and Casida (10) differ from phytopathogenic bacteria belonging to the genus Clavibacter mainly in the following characteristics: formation of true mycelia, menaquinone composition, and a number of physiological characteristics. These actinomycetes (in particular, the genus Agromyces as originally described) have been characterized as being catalase and oxidase negative (10).

Only one species of the genus Agromyces, Agromyces ramosus, has been described previously. Most chemotaxonomic characteristics (the exceptions are the differential amino acids and the major cell wall sugars) have been determined only for the type strain of $A$. ramosus, strain ATCC $25173(2,3,10,15)$. As far as we know, at present only one strain of $A$. ramosus is kept in culture collections.

In 1985, we isolated from soils 14 strains of aerobic, catalase- and oxidase-positive actinomycetes that have yellow fragmenting mycelia and contain diaminobutyric acid in their cell walls (9). The results of a preliminary characteri-

\footnotetext{
* Corresponding author.
}

zation of these strains in which they were compared with the previously published descriptions of several taxa showed that they are most similar to $A$. ramosus but differ from this species in a number of characteristics $(2,9)$.

In this paper we describe the results of a comparative study of the 14 isolates obtained from soil, as well as the type strain of $A$. ramosus (strain ATCC 25173) and representatives of the genus Clavibacter.

\section{MATERIALS AND METHODS}

Bacterial strains. The strains were isolated from soil samples that were obtained in the Moscow Region of Russia. The Agromyces and Clavibacter type strains were obtained from the American Type Culture Collection (ATCC), Rockville, Md., and the International Collection of Microorganisms from Plants (ICMP), Auckland, New Zealand. The strains used in this work are shown in Tables 1 through 3 and Fig. 1.

Morphology. Morphological characteristics were determined by using phase-contrast microscopy of 3- and 7-dayold cultures that were grown on peptone-yeast extract agar ( $5 \mathrm{~g}$ of peptone, $3 \mathrm{~g}$ of yeast extract, $5 \mathrm{~g}$ of glucose, $0.2 \mathrm{~g}$ of $\mathrm{K}_{2} \mathrm{HPO}_{4}, 1$ liter of distilled water, $15 \mathrm{~g}$ of agar).

Physiology. Utilization of carbohydrates was tested by using modified Pridham-Gottlieb medium (23) supplemented with $0.01 \%$ yeast extract and glucose or other carbon sources at final concentrations of $1 \%$. Modified Pridham- 
TABLE 1. Sugar compositions of whole cells of Agromyces strains

\begin{tabular}{|c|c|c|c|c|c|c|c|c|}
\hline \multirow{2}{*}{ Strain } & \multicolumn{8}{|c|}{ Presence of ${ }^{a}:$} \\
\hline & Galactose & Glucose & Mannose & Xylose & Ribose & Fucose & Rhamnose & Tyvelose \\
\hline A. ramosus ATCC 25173 & $(+)$ & + & + & + & + & - & + & - \\
\hline \multicolumn{9}{|l|}{ A. cerinus subsp. cerinus } \\
\hline VKM Ac- $1340^{\mathrm{T}}$ & + & + & + & + & + & - & + & + \\
\hline VKM Ac-1341 & + & + & + & + & + & - & + & + \\
\hline VKM Ac- 1342 & + & + & + & $(+)$ & + & - & + & + \\
\hline VKM Ac- 1343 & + & + & + & $(+)$ & + & - & + & + \\
\hline VKM Ac-1344 & + & + & + & $(+)$ & + & - & + & $(+)$ \\
\hline VKM Ac-1350 & + & + & + & $(+)$ & + & - & + & + \\
\hline $\begin{array}{l}\text { A. cerinus subsp. nitratus } \\
\text { VKM Ac- } 1351^{\mathrm{T}}\end{array}$ & + & + & + & + & + & - & - & - \\
\hline \multicolumn{9}{|l|}{ A. fucosus subsp. fucosus } \\
\hline VKM Ac- $1345^{\mathrm{T}}$ & + & + & + & - & + & + & + & - \\
\hline VKM Ac-1346 & + & + & + & - & + & + & + & - \\
\hline VKM Ac-1347 & $(+)$ & + & + & - & + & $(+)$ & + & - \\
\hline VKM Ac-1348 & + & + & + & - & + & $(+)$ & + & - \\
\hline VKM Ac-1349 & + & + & + & - & + & $(+)$ & + & - \\
\hline \multicolumn{9}{|l|}{ A. fucosus subsp. hippuratus } \\
\hline VKM Ac- $1352^{\mathrm{T}}$ & + & + & + & $(+)$ & + & $(+)$ & + & - \\
\hline VKM Ac-1353 & + & + & + & $(+)$ & + & $(+)$ & + & - \\
\hline
\end{tabular}

${ }^{a}+$, detected;,- not detected; $(+)$, detection weak or questionable.

Gottlieb medium which contained $15 \mathrm{ml}$ of $0.03 \%$ bromocresol purple was used to test the production of acids from carbohydrates and related carbon sources, and modified Pridham-Gottlieb medium which contained $15 \mathrm{ml}$ of $0.03 \%$ phenol red was used to test the utilization of organic acids. Utilization of amino acids as $\mathbf{N}$ sources was tested by using previously described methods (11). Catalase production was determined by mixing a fresh colony of bacteria with 1 drop of $3 \%$ hydrogen peroxide. Production of oxidase was tested by using the method of Kovacs (16). Susceptibility to growth inhibitors and antibiotics was tested on peptone-yeast extract agar. Degradation activity and additional biochemical characteristics were determined by using previously described methods $(5,12,13)$.

Analysis of phenotypic data. Similarities were calculated by using the simple matching coefficient and the Jaccard coefficient. The BIOMATRIX copackage was used for cluster analysis (22).

Chemotaxonomy. Cell wall peptidoglycan preparations were obtained by using the methods of Schleifer and Kandler (24). Peptidoglycan amino acids were assayed by using a model LC600 amino acid analyzer (Biotronic, Munich, Germany). The sugar compositions of hydrolysates of whole cells and cell walls that were purified by using enzymes $(0.01$ $\mathrm{mg}$ of DNase per ml; $0.1 \mathrm{mg}$ of pronase per ml; $0.1 \mathrm{mg}$ of trypsin per ml; $0.05 \mathrm{M}$ sodium phosphate buffer [ $\mathrm{pH} 7.0]$ ) were analyzed by chromatographic methods $(14,17)$. Cellular fatty acid methyl ethers were determined by using previously described methods (8). Menaquinones were extracted and purified by using the method of Collins (4); the menaquinone compositions were determined by using a model MAT 8430 mass spectrometer (Finnigan, Bremen, Germany). Phospholipids were isolated, analyzed by thinlayer chromatography, and identified by using the method of Minnikin et al. (20).

Polyacrylamide gel electrophoresis. Gradient slab gels were used as described by Carlson and Vidaver (1). Cells were grown aerobically in peptone-yeast extract medium for $24 \mathrm{~h}$ at $27^{\circ} \mathrm{C}$.

DNA base composition and DNA-DNA hybridization. DNA was prepared as described previously $(6,8)$. The $\mathrm{G}+\mathrm{C}$ content of each DNA was determined from its thermal denaturation midpoint $\left(T_{m}\right)(18)$ in $0.1 \times \mathrm{SSC}(1 \times \mathrm{SSC}$ is 0.15 $\mathrm{M} \mathrm{NaCl}$ plus $0.015 \mathrm{M}$ sodium citrate) by using a Beckman model DU-8B spectrophotometer equipped with a thermoprogrammer. DNA base composition was calculated by using the equation of Owen and Pitcher (21). DNA from Micrococcus luteus VKM B-1314 ${ }^{\mathrm{T}}$ ( $\mathrm{T}=$ type strain), which has a $\mathrm{G}+\mathrm{C}$ content of $72 \mathrm{~mol} \%(21)$, was used as a reference. The levels of DNA reassociation between strains were determined by using the membrane filter method $(19,25)$, as described previously (8).

\section{RESULTS}

Morphological and chemotaxonomic characteristics, such as peptidoglycan amino acid composition (2,4-diaminobutyric acid, alanine, glutamic acid, and glycine, 2:1:1:1), diagnostic phospholipids (phosphatidylglycerol and diphosphatidylglycerol), and predominant menaquinones (MK-12), were similar in the 14 soil isolates which we studied and were the same as the characteristics of the type strain of $A$. ramosus, strain ATCC 25173.

All of the strains which we studied except the type strain of $A$. ramosus grew well aerobically and were catalase and oxidase positive.

The following sugars were found in the whole-cell hydrolysates: galactose, glucose, mannose, ribose, rhamnose, xylose, fucose, and tyvelose $(7,17)$ (Table 1$)$. Not all of the sugars were present in the cell walls of all of the strains. Galactose, glucose, rhamnose, tyvelose, fucose, mannose, and ribose were detected in all or some preparations of purified cell walls (Table 2); xylose was also present in the native cell walls (17). The majority of the strains could be grouped on the basis of the presence of fucose and tyvelose in whole-cell hydrolysates or in purified cell walls (Tables 1 and 2). Xylose was detected in all of the hydrolysates containing tyvelose except the strain VKM Ac-1351 T hydrolysate. Strains VKM Ac-1352 ${ }^{\mathrm{T}}$ and VKM Ac-1353, which contained fucose, also contained xylose. 
TABLE 2. Cell wall sugars of Agromyces strains

\begin{tabular}{|c|c|c|c|c|c|c|c|}
\hline \multirow{2}{*}{ Strain } & \multicolumn{7}{|c|}{ Molar ratio ${ }^{a}$} \\
\hline & Galactose & Glucose & Mannose & Ribose & Fucose & Rhamnose & Tyvelose \\
\hline \multicolumn{8}{|l|}{ A. cerinus subsp. cerinus } \\
\hline VKM Ac- $1340^{\mathrm{T}}$ & 1 & & 0.3 & & & 3.4 & 3.5 \\
\hline VKM Ac-1341 & 1 & & & & & 1.2 & 2.1 \\
\hline VKM Ac-1342 & 1 & & & & & 2.5 & 0.8 \\
\hline VKM Ac- 1343 & 1 & & & & & 2.3 & 1.3 \\
\hline VKM Ac-1344 & 1 & $\operatorname{Tr}$ & 0.2 & & & 3.5 & 0.6 \\
\hline VKM Ac-1348 & 1 & & & & & 1.7 & 1.1 \\
\hline $\begin{array}{l}\text { A. cerinus subsp, nitratus } \\
\text { VKM Ac- } 1351^{\mathrm{T}}\end{array}$ & 1 & 0.3 & $\operatorname{Tr}$ & 0.2 & & & \\
\hline \multicolumn{8}{|l|}{ A. fucosus subsp. fucosus } \\
\hline VKM Ac- $1345^{\mathrm{T}}$ & 1 & & $\operatorname{Tr}$ & & 0.9 & 0.6 & \\
\hline VKM Ac-1346 & 1 & 4.6 & & & 2.5 & 3.8 & \\
\hline VKM Ac-1347 & 1 & & & & & 7.0 & \\
\hline VKM Ac-1349 & 1 & & $\operatorname{Tr}$ & & & 2.3 & \\
\hline \multicolumn{8}{|c|}{ A. fucosus subsp. hippuratus } \\
\hline VKM Ac- $1352^{\mathrm{T}}$ & 1 & & & & & 13.8 & \\
\hline VKM Ac- 1353 & 1 & & $\operatorname{Tr}$ & & & 8.5 & \\
\hline
\end{tabular}

${ }^{a}$ The galactose level was defined as $1 . \operatorname{Tr}$, trace.

The whole-cell protein patterns appeared to be rather similar in all of the strains which we studied. The type strain of $A$. ramosus differed from the other strains to the greatest extent. The protein patterns of the strains that had similar cell wall sugar compositions were most similar to each other.

The DNA G $+\mathrm{C}$ contents of the strains which we studied, including the type strain of $A$. ramosus, ranged from 70 to 72 mol\%.

The level of DNA-DNA relatedness between the type strain of $A$. ramosus and reference strain VKM Ac- $1340^{\mathrm{T}}$ was $12 \%$. At least two groups among all of the isolates were identified on the basis of levels of DNA-DNA relatedness (Table 3). Strains belonging to the first group (which as a rule contained tyvelose in their cell walls) exhibited rather high levels of DNA-DNA relatedness (68 to 92\%) and were considered to be members of one genospecies (19). It should

TABLE 3. Levels of DNA-DNA relatedness between strain VKM Ac- $1340^{\mathrm{T}}$ and Agromyces spp. strains

\begin{tabular}{|c|c|}
\hline Strain & $\begin{array}{c}\text { \% Relatedness to } \\
{\left[{ }^{3} \mathrm{H}\right] \text { DNA from }} \\
\text { strain VKM } \\
\text { Ac- } 1340^{\mathrm{T}}\end{array}$ \\
\hline \multicolumn{2}{|l|}{ A. cerinus subsp. cerinus } \\
\hline VKM Ac- $1340^{\mathrm{T}} \ldots \ldots \ldots \ldots$ & 100 \\
\hline VKM Ac-1341 ................. & 92 \\
\hline VKM Ac-1342 ................. & 88 \\
\hline 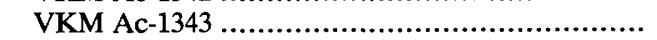 & 71 \\
\hline \multicolumn{2}{|l|}{ A. cerinus subsp. nitratus } \\
\hline VKM Ac- $1351^{\mathrm{T}}$ & 68 \\
\hline \multicolumn{2}{|l|}{ A. fucosus subsp. fucosus } \\
\hline VKM Ac- $1345^{\mathrm{T}} \ldots \ldots \ldots \ldots$ & 40 \\
\hline VKM Ac-1348 ................ & 45 \\
\hline 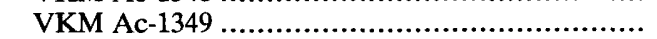 & 47 \\
\hline \multicolumn{2}{|l|}{ A. fucosus subsp. hippuratus } \\
\hline 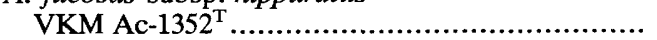 & 48 \\
\hline VKM Ac-1353 & 45 \\
\hline A. ramosus ATCC 25173 .............................. & 12 \\
\hline Clavibacter michiganensis subsp. ICMP $2550^{\mathrm{T}} \ldots \ldots$ & 10 \\
\hline Clavibacter rathayi ${ }^{a}$ ICMP $2574^{\mathrm{T}} \ldots \ldots \ldots \ldots \ldots \ldots \ldots \ldots$ & 12 \\
\hline
\end{tabular}

${ }^{a}$ It has been proposed that this organism should be transferred to Rathayibacter gen. nov. (26). be noted that this genospecies also contained strain VKM Ac- $1351^{\mathrm{T}}$, which differed from the majority of the isolates by lacking rhamnose and tyvelose in its cell wall and by some physiological characteristics (Tables 1, 2, and 4).

The levels of DNA-DNA relatedness between strain VKM Ac- $1340^{\mathrm{T}}$ and strains belonging to the other group (strains VKM Ac-1345 ${ }^{\mathrm{T}}$, VKM Ac-1348, VKM Ac-1349, VKM Ac$1352^{\mathrm{T}}$, and VKM Ac-1353) ranged from 40 to $48 \%$ (the whole-cell protein patterns of these strains were similar).

Our numerical analysis of strains of Agromyces spp. and Clavibacter strains based on 135 physiological and biochemical characteristics showed that all of the Agromyces strains which we studied formed one cluster (simple matching coefficient, 80\%; Jaccard coefficient, 68\%) (Fig. 1). Within the Agromyces spp. cluster, three subclusters (subclusters A, B, and C) stood out clearly. Subcluster A contained strains that had DNA complementarity levels ranging from 71 to $92 \%$ and tyvelose in their cell walls. Subcluster B consisted of five strains that had fucose in their whole-cell hydrolysates and exhibited levels of DNA-DNA relatedness with strain VKM Ac- $1340^{\mathrm{T}}$ of 40 to $48 \%$. Subcluster C contained three strains which belonged to various genospecies and had different cell wall sugar compositions.

The differential physiological properties of the strains which we studied are summarized in Table 4. Detailed characterizations of the physiological properties are given below in the descriptions of the new species and the emended description of the genus Agromyces.

\section{DISCUSSION}

Chemotaxonomic characteristics and the levels of DNA relatedness (Table 3) supported the suggestion that the strains which we studied and the type strain of $A$. ramosus (strain ATCC 25173) belong to a single genus.

Taking into account phenotypic differences, we believe that the newly described strains belong to species that are different from $A$. ramosus.

We propose that the majority of the strains should be classified in two species, Agromyces cerinus sp. nov. and Agromyces fucosus sp. nov., on the basis of their inclusion 
TABLE 4. Characteristics that differentiate species and subspecies of the genus Agromyces

\begin{tabular}{|c|c|c|c|c|c|}
\hline Characteristic & $\begin{array}{l}\text { A. ramosus } \\
(60 \text { strains })^{a}\end{array}$ & $\begin{array}{l}\text { A. cerinus subsp. } \\
\text { cerinus } \\
\text { (6 strains) }\end{array}$ & $\begin{array}{c}\text { A. cerinus subsp. } \\
\text { nitratus } \\
\text { (1 strain) }\end{array}$ & $\begin{array}{l}\text { A. fucosus subsp. } \\
\text { fucosus } \\
\text { (5 strains) }\end{array}$ & $\begin{array}{l}\text { A. fucosus subsp. } \\
\text { hippuratus } \\
\text { (2 strains) }\end{array}$ \\
\hline \multicolumn{6}{|l|}{ Sugars in whole-cell hydrolysates } \\
\hline Tyvelose & $\mathrm{ND}^{b}$ & $100^{c}$ & - & $0^{c}$ & $0^{c}$ \\
\hline Xylose & $77^{d}$ & 100 & + & 0 & 100 \\
\hline Fucose & 0 & 0 & - & 100 & 100 \\
\hline Rhamnose & 100 & 100 & - & 100 & 100 \\
\hline Catalase activity & 0 & 100 & + & 100 & 100 \\
\hline Benzidine test & 0 & 100 & + & 100 & 100 \\
\hline \multicolumn{6}{|l|}{$\begin{array}{l}\text { Utilization of the following compounds } \\
\text { as } C \text { sources: }\end{array}$} \\
\hline Inositol & ND & 83 & - & 0 & 0 \\
\hline Starch & ND & 0 & + & 100 & 100 \\
\hline Lysin & ND & 16 & + & 80 & 50 \\
\hline \multicolumn{6}{|l|}{ Acid production from: } \\
\hline L-Arabinose & $97^{d}$ & 0 & - & 100 & 100 \\
\hline Xylose & $95^{d}$ & 0 & - & $60^{d}$ & 100 \\
\hline Lactose & 10 & 100 & - & $80^{d}$ & 0 \\
\hline Raffinose & $98^{d}$ & 0 & - & 60 & 0 \\
\hline Salicin & 13 & 100 & - & $60^{d}$ & 0 \\
\hline Sucrose & $92^{d}$ & 0 & - & 100 & 0 \\
\hline Fructose & 100 & 50 & - & 100 & 0 \\
\hline \multicolumn{6}{|c|}{ Utilization of the following organic acids: } \\
\hline Aconitate & ND & 0 & + & 0 & 50 \\
\hline Formate & ND & 0 & + & 0 & 0 \\
\hline Citrate & 5 & 100 & + & 20 & 0 \\
\hline Succinate & ND & 83 & + & 80 & 0 \\
\hline \multicolumn{6}{|l|}{ Degradation of: } \\
\hline Hippurate & ND & 0 & + & $20^{d}$ & 100 \\
\hline Tyrosine & 0 & 0 & + & 20 & 100 \\
\hline $\mathrm{NO}_{3}$ reduction & 15 & 0 & + & 0 & 100 \\
\hline Growth at $37^{\circ} \mathrm{C}$ & $\mathrm{ND}^{d}$ & 0 & + & 0 & 0 \\
\hline Growth in the presence of $4 \% \mathrm{NaCl}$ & 57 & 0 & - & 0 & 0 \\
\hline Antibiosis to Bacillus subtilis & ND & 0 & - & 0 & $50^{d}$ \\
\hline
\end{tabular}

a Data from reference 10 .

$b$ ND, no data available.

$c$ Percentage of positive strains.

${ }^{d}$ The reaction of the type strain is positive.

in subclusters A and B (Fig. 1) and belong to different genospecies (Table 3).

Strain VKM Ac- $1351^{\mathrm{T}}$ differed from the other strains in its cell wall sugars and in a number of phenotypic characteristics (Table 4) but exhibited a level of DNA relatedness of $68 \%$ with other representatives of $A$. cerinus; this strain is a member of a subspecies of $A$. cerinus, $A$. cerinus subsp. nitratus subsp. nov. (named for its ability to reduce nitrate).

Two strains, strains VKM Ac- $1352^{\mathrm{T}}$ and VKM Ac-1353, differed from the major group of strains on the basis of the results of a numerical analysis (Fig. 1 and Table 4) but were closely related to $A$. fucosus on the basis of whole-cell sugar compositions and whole-cell protein patterns and are classified as members of $A$. fucosus subsp. hippuratus subsp. nov. (named for its ability to hydrolyze hippurate).

Characteristics of the new species and subspecies are given below in their descriptions.

Below we also give an emended description of the genus Agromyces, which is based on the results of a study of 14 original strains and $A$. ramosus ATCC $25173^{\mathrm{T}}$ and on previously described data $(2,3,10,15)$.

Most of the strains studied by Gledhill and Casida and assigned to $A$. ramosus are heterogeneous in physiological properties and cell wall sugar composition. It is possible that some of these strains do not belong to the species $A$. ramosus. However, since these strains were not deposited in accessible culture collections, we could not confirm this hypothesis.

Emended description of the genus Agromyces. Agromyces (Ag.ro.my'ces. Gr. n. agros, field or soil; Gr. n. myces, fungus; M.L.n. Agromyces, soil fungus). Branching hyphae (width, 0.3 to $0.6 \mu \mathrm{m}$ ) break up into diphtheroid and rodlike, irregular, nonmotile fragments. No endo- and exospores are formed. Colonies on peptone-yeast extract medium are opaque, entire, and convex and sometimes penetrate into the agar. Rough colony variants occur. Produces a yellow carotenoid pigment.

Gram positive. Not acid fast. Aerobic to microaerophilic. Catalase and oxidase activities are variable for different species. Chemoorganotrophic. Glucose is metabolized oxidatively. Utilizes a wide range of $\mathrm{C}$ and $\mathrm{N}$ sources. Grows on media supplemented with inorganic nitrogen; organic nitrogen is required for growth of some strains. Mesophilic. Optimal growth occurs at temperatures between 26 and $30^{\circ} \mathrm{C}$; some strains grow at $37^{\circ} \mathrm{C}$. The Voges-Proskauer test is negative.

The peptidoglycan contains 2,4-diaminobutyric acid, alanine, glutamic acid, and glycine (molar ratio, 2:1:1:1). Galactose and rhamnose occur in the cell walls of most strains; fucose, tyvelose, glucose, mannose, xylose, or ribose may also be present. Mycolic acids are not present. Diagnostic polar lipids are represented by diphosphatidylglycerol and 


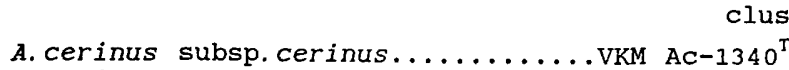

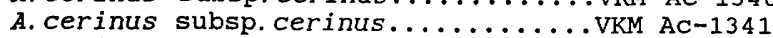

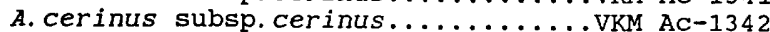

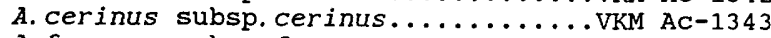

A. fucosus subsp. fucosus................ VKM AC-1349

A. fucosus subsp. fucosus.............. VKM AC-1347

A. fucosus subsp. fucosus.............. VKM Ac-1346

A. fucosus subsp. fucosus................. AKM Ac-1348

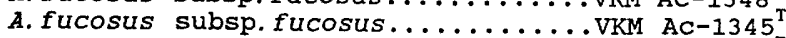

A. cerinus subsp. nitratus............................ ACM $-1351^{\mathrm{T}}$

A. fucosus subsp.hippuratus.......................... AC-1352

A. fucosus subsp.hippuratus.............VKM AC-1353

C. michiganensis subsp. insidiosus.... IMET 10505

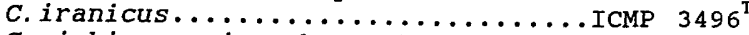

C. michiganensis subsp. nebraskensis...IMET 10515

C. michiganensis subsp.tessellarius. ICMP 7221

C. michiganensis subsp.nebraskensis.. ICMP $3298^{\mathrm{T}}$

C. michiganensis subsp. michiganensis ICMP $2550^{\mathrm{T}}$

C. michiganensis subsp. michiganensis VKM Ac-1114

C. michiganensis subsp. sepedonicus....IMET 11006

C. michiganensis subsp.michiganensis IMET 10903

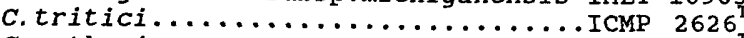

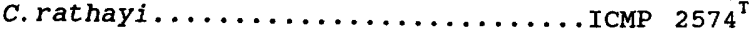

C. michiganensis subsp. insidiosus..... ICMP $2621^{\mathrm{T}}$

$I / A /$
$I / C$
$I I$
$I I I$
$I V$

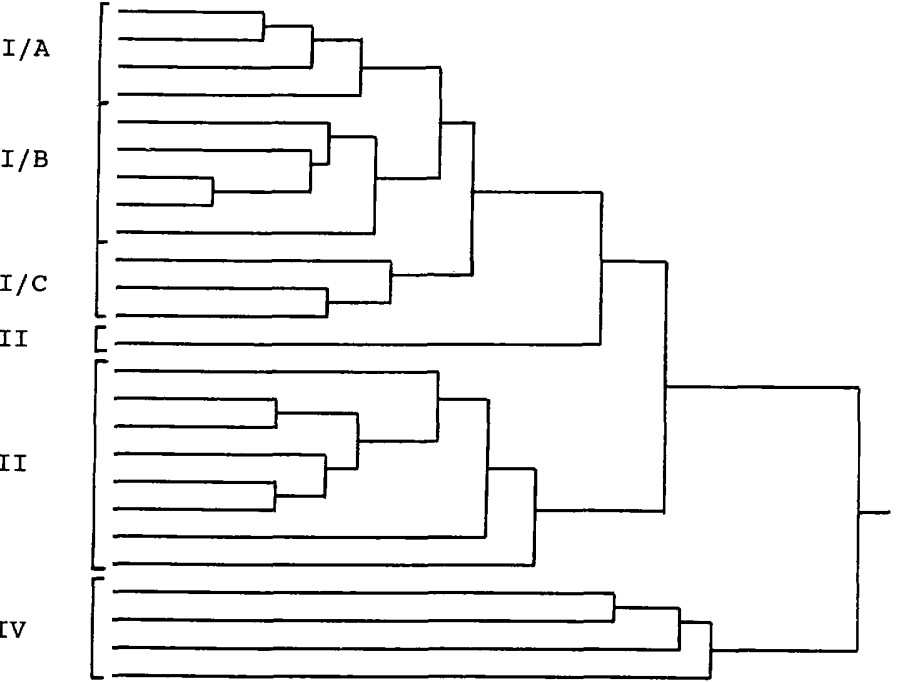

FIG. 1. Dendrogram showing the relationships among strains belonging to Agromyces and Clavibacter species. The dendrogram was based on 135 physiological characteristics and was drawn by using Jaccard coefficient values.

phosphatidylglycerol. The major menaquinone type is MK12. Iso- and anteiso-branching fatty acids predominate (up to $94 \%$ of the total fatty acids). The $\mathrm{G}+\mathrm{C}$ content of the DNA is 70 to $72 \mathrm{~mol} \%$ (as determined by the $T_{m}$ method).

Found mainly in soils.

The type species of the genus Agromyces is Agromyces ramosus Gledhill and Casida $1969,365^{\mathrm{Al}}$.

Additional descriptive information. The majority of the strains of the genus grow on media containing D-arabinose, cellobiose, D-fructose, D-galactose, D-glucose, methyl- $\alpha$-Dglucoside, methyl- $\beta$-D-glucopyranoside, inulin, maltose, D-mannose, melezitose, raffinose, L-rhamnose, salicin, sucrose, or trehalose as a carbon source. Dulcitol, mesoerythritol, D-mannitol, methyl- $\beta$-D-arabinopyranoside, and sorbose are not used as sole carbon sources. Acids are produced from cellobiose, D-galactose, D-mannose, and L-rhamnose; no acids are formed from meso-inositol and D-mannitol. An alkaline reaction occurs with fumarate. trans-Aconitate, ascorbate, gluconate, oxalate, salicylate, and tartrate are not utilized. L-Asparagine is used as a sole $\mathbf{N}$ source; arginine, methionine, norleucine, phenylalanine, threonine, tryptophan, tyrosine, and valine are not utilized as $\mathbf{N}$ sources. Phenylalanine is not deaminated.

Esculin and arbutin are hydrolyzed; casein, elastin, guanine, hypoxanthine, pectin, testosterone, Tween 21 , Tween 60 , Tween 80 , urea, and xanthine usually are not decomposed. All strains are susceptible to bacitracin $(10 \mu \mathrm{g} / \mathrm{ml})$, tetracycline $(30 \mu \mathrm{g} / \mathrm{ml})$, novobiocin $(30 \mu \mathrm{g} / \mathrm{ml})$, erythromycin (15 $\mu \mathrm{g} / \mathrm{ml})$, neomycin $(30 \mu \mathrm{g} / \mathrm{ml})$, rifampin $(5 \mu \mathrm{g} / \mathrm{ml})$, kanamycin $(30 \mu \mathrm{g} / \mathrm{ml})$, and vancomycin $(30 \mu \mathrm{g} / \mathrm{ml})$ and are resistant to clindamycin $(2 \mu \mathrm{g} / \mathrm{ml})$ and nalidixic acid (30 $\mu \mathrm{g} / \mathrm{ml})$. No growth occurs in the presence of $4 \% \mathrm{NaCl}$, $0.01 \%$ sodium azide, and $0.0175 \%$ potassium tellurite.

The following tests are variable: utilization of adonitol, L-arabinose, meso-inositol, melibiose, starch, and D-xylose; acid production from L-arabinose, cellobiose, D-fructose, D-glucose, meso-inositol, lactose, maltose, D-mannitol, D-mannose, melibiose, raffinose, salicin, sucrose, trehalose, and D-xylose; alkaline reaction with fumarate, citrate, $\alpha$-ketoglutarate, succinate, or valerate; use of asparagine, lysine, or serine as a sole $\mathbf{N}$ source; hydrolysis of hippurate, starch, Tween 40, and tyrosine; $\mathrm{NO}_{3}$ reduction; susceptibility to ampicillin $(10 \mu \mathrm{g} / \mathrm{ml})$, gentamicin $(10 \mu \mathrm{g} / \mathrm{ml})$, penicillin $(10$ $\mu \mathrm{g} / \mathrm{ml})$, rifampin $(50 \mu \mathrm{g} / \mathrm{ml})$, and streptomycin $(10 \mu \mathrm{g} / \mathrm{ml})$; and growth at $37^{\circ} \mathrm{C}$.

Description of Agromyces cerinus sp. nov. Agromyces cerinus (ce.ri'nus. M.L. adj. cerinus, honey yellow). Branching hyphae (width, 0.2 to $0.6 \mu \mathrm{m}$ ) break up into diphtheroid and rodlike, irregular, nonmotile fragments. Colonies on peptone-yeast extract medium are opaque, entire, and convex and penetrate into the agar. Produces a yellow carotenoid pigment.

In most strains the cell wall contains galactose, rhamnose, tyvelose, and xylose.

Ammonium ions are usually assimilated as a sole $\mathrm{N}$ source. Organic nitrogen is required for good growth of only some strains. D-Arabinose, cellobiose, D-fructose, D-galactose, D-glucose, inulin, maltose, D-mannose, melezitose, methyl- $\alpha$-D-glucoside, methyl- $\beta$-D-glucoside, raffinose, Lrhamnose, salicin, sucrose, and trehalose are used as sole $\mathrm{C}$ sources. Does not utilize dulcitol, i-erythritol, D-mannitol, methyl- $\beta$-D-arabinopyranoside, or sorbose as a sole $\mathrm{C}$ source. Acids are produced from cellobiose, D-galactose, D-mannose, and L-rhamnose, and no acids are formed from L-arabinose, meso-inositol, melibiose, raffinose, sucrose, and D-xylose.

Alkaline reactions occur with citrate, fumarate, $\alpha$-ketoglutarate, and succinate, but aconitate, ascorbate, gluconate, salicylate, oxalate, tartrate, and usually formate are not utilized. Arginine, methionine, norleucine, phenylalanine, threonine, tryptophan, tyrosine, and valine are not utilized as $\mathrm{N}$ sources. Deamination of phenylalanine is negative.

Usually nitrate reduction does not occur. The VogesProskauer test is negative.

Esculin and arbutin are hydrolyzed; casein, elastin, gua- 
nine, hypoxanthine, pectin, testosterone, Tween 21 , Tween 60 , Tween 80 , and xanthine are not decomposed. Tyrosine and Tween 40 are decomposed by most strains. No growth occurs on media supplemented with $7 \% \mathrm{NaCl}, 0.01 \%$ sodium azide, or $0.0175 \%$ potassium tellurite. Susceptible to ampicillin $(10 \mu \mathrm{g} / \mathrm{ml})$, bacitracin $(10 \mu \mathrm{g} / \mathrm{ml})$, erythromycin $(15$ $\mu \mathrm{g} / \mathrm{ml})$, kanamycin $(30 \mu \mathrm{g} / \mathrm{ml})$, neomycin $(30 \mu \mathrm{g} / \mathrm{ml})$, novobiocin $(30 \mu \mathrm{g} / \mathrm{ml})$, rifampin $(5 \mu \mathrm{g} / \mathrm{ml})$, tetracycline $(30 \mu \mathrm{g} / \mathrm{ml})$, and vancomycin $(30 \mu \mathrm{g} / \mathrm{ml})$ but resistant to clindamycin $(2$ $\mu \mathrm{g} / \mathrm{ml})$, nalidixic acid $(30 \mu \mathrm{g} / \mathrm{ml})$, and penicillin $(10 \mu \mathrm{g} / \mathrm{ml})$.

The following tests are variable: utilization of $\mathrm{L}$-arabinose, meso-inositol, and melibiose as sole $\mathrm{C}$ sources; acid production from D-fructose, D-glucose, lactose, maltose, D-mannitol, salicin, and trehalose; utilization of formate, transaconitate, or valerate; assimilation of asparagine, lysine, and serine as $\mathrm{N}$ sources; hydrolysis of hippurate and starch; susceptibility to gentamicin $(10 \mu \mathrm{g} / \mathrm{ml})$, rifampin $(50 \mu \mathrm{g} / \mathrm{ml})$, and streptomycin $(10 \mu \mathrm{g} / \mathrm{ml})$; and growth at $37^{\circ} \mathrm{C}$.

The $\mathrm{G}+\mathrm{C}$ content of the DNA is $72 \mathrm{~mol} \%$ (as determined by the $T_{m}$ method).

Isolated from soil.

The type strain of $A$. cerinus is strain VKM Ac- 1340 .

The description given above was based on seven strains.

Description of Agromyces cerinus subsp. cerinus sp. nov., subsp. nov. Strains of $A$. cerinus subsp. cerinus are distinguished by a specific cell wall sugar composition; tyvelose, xylose, and rhamnose are present.

Most strains grow on medium containing meso-inositol. Acids are produced from lactose, salicin, or trehalose. Acids are not produced from L-arabinose, inulin, or D-mannitol. trans-Aconitate and formate are not utilized. Nitrate is not reduced. Tyrosinase activity is negative. Hippurate is not hydrolyzed. Organic nitrogen is not required for good growth. No growth occurs at $37^{\circ} \mathrm{C}$.

The $\mathrm{G}+\mathrm{C}$ content of the DNA is $72 \mathrm{~mol} \%$ (as determined by the $T_{m}$ method).

The type strain of $A$. cerinus subsp. cerinus is strain VKM Ac-1340.

The description given above was based on six strains.

Description of Agromyces cerinus subsp. nitratus sp. nov., subsp. nov. Agromyces cerinus subsp. nitratus (ni.tra'tus. N.L. n. nitratum, nitrate; N.L. adj. nitratus, decomposed nitrate) is distinguished from $A$. cerinus subsp. cerinus by the absence of rhamnose, tyvelose, and xylose and the presence of glucose and ribose in the cell walls. Organic nitrogen is required for good growth. Grows on media containing $\mathrm{L}$-arabinose, maltose, melibiose, and starch as $\mathrm{C}$ sources. Produces acid from maltose or mannitol; acids are not produced from $D$-fructose, meso-inositol, lactose, salicin, and trehalose. Utilizes formate and trans-aconitate. Valerate is not utilized. Starch and Tween 40 are decomposed. Reduces nitrate and produces tyrosinase. Grows at $37^{\circ} \mathrm{C}$. The $\mathrm{G}+\mathrm{C}$ content of the DNA is $72 \mathrm{~mol} \%$ (as determined by the $T_{m}$ method).

The type strain of $A$. cerinus subsp. nitratus is strain VKM Ac-1351.

The description given above was based on one strain.

Description of Agromyces fucosus sp. nov. Agromyces fucosus (fu.co'sus. N.L. n. fucosum, fucose; N.L. adj. fucosus, containing fucose in the cell wall). Branching hyphae (width, 0.2 to $0.6 \mu \mathrm{m}$ ) break up into diphtheroid and rodlike, irregular, nonmotile fragments. Colonies on peptone-yeast extract medium are opaque, entire, and convex and sometimes penetrate into the agar. Rough colony variants occur. Produces a yellow carotenoid pigment.
The whole-cell hydrolysates contain galactose, rhamnose, fucose, mannose, and glucose as major sugars.

Organic nitrogen is not required for good growth.

Most strains grow on media containing $D$-arabinose, cellobiose, D-fructose, D-galactose, D-glucose, inulin, maltose, $D$-mannose, melezitose, methyl- $\beta$-D-glucoside, methyl- $\alpha-D-$ glucoside, raffinose, L-rhamnose, salicin, starch, sucrose, trehalose, or D-xylose as a sole carbon source; dulcitol, i-erythritol, meso-inositol, D-mannitol, methyl- $\beta$-D-arabinopyranoside, and L-sorbose are not used as sole carbon sources. Acids are produced from L-arabinose, cellobiose, D-galactose, D-mannose, L-rhamnose, and D-xylose. No acids are formed from D-glucose and meso-inositol. Ascorbate, trans-aconitate, citrate, formate, gluconate, oxalate, salicylate, and tartrate are not utilized. Arginine, methionine, norleucine, phenylalanine, threonine, tryptophan, tyrosine, and valine are not utilized as $\mathrm{N}$ sources. Does not deaminate phenylalanine. Esculin, arbutin, and starch are decomposed; casein, elastin, guanine, hypoxanthine, pectin, testosterone, Tween 21, Tween 40, Tween 60 , Tween 80 , urea, and xanthine are not decomposed. All strains are susceptible to bacitracin $(10 \mu \mathrm{g} / \mathrm{ml})$, erythromycin $(15 \mu \mathrm{g})$ $\mathrm{ml})$, gentamicin $(10 \mu \mathrm{g} / \mathrm{ml})$, kanamycin $(30 \mu \mathrm{g} / \mathrm{ml})$, neomycin $(30 \mu \mathrm{g} / \mathrm{ml})$, novobiocin $(30 \mu \mathrm{g} / \mathrm{ml})$, rifampin $(5 \mu \mathrm{g} / \mathrm{ml})$, rifampin $(50 \mu \mathrm{g} / \mathrm{ml})$, tetracycline $(30 \mu \mathrm{g} / \mathrm{ml})$, and vancomycin $(30 \mu \mathrm{g} / \mathrm{ml})$ and resistant to clindamycin $(2 \mu \mathrm{g} / \mathrm{ml})$ and nalidixic acid $(30 \mu \mathrm{g} / \mathrm{ml})$. No growth occurs on media supplemented with $7 \% \mathrm{NaCl}, 0.01 \%$ sodium azide, or $0.0175 \%$ potassium tellurite. No growth occurs at $37^{\circ} \mathrm{C}$.

The Voges-Proskauer test is negative.

The following tests are variable: utilization of adonitol, meso-inositol, and melibiose; production of acids from cellobiose, D-fructose, inulin, D-glucose, lactose, maltose, D-mannitol, melibiose, raffinose, salicin, sucrose, and trehalose; utilization of fumarate, $\alpha$-ketoglutarate, succinate, trans-aconitate, and valerate; decomposition of hippurate and tyrosine; nitrate reduction; and susceptibility to ampicillin $(10 \mu \mathrm{g} / \mathrm{ml})$, penicillin $(10 \mu \mathrm{g} / \mathrm{ml})$, and streptomycin $(10 \mu \mathrm{g} / \mathrm{ml})$. The $\mathrm{G}+\mathrm{C}$ contents of the DNAs are 70 to 72 mol\% (as determined by the $T_{m}$ method).

Isolated from soil.

The type strain of $A$. fucosus is strain VKM Ac- 1345 .

The description given above was based on seven strains.

Description of Agromyces fucosus subsp. fucosus sp. nov., subsp. nov. Members of $A$. fucosus subsp. fucosus are distinguished from strains belonging to the other subspecies by the presence of fucose and glucose in their cell walls and by the absence of xylose in their whole-cell hydrolysates.

Most strains grow on media containing L-arabinose, starch, and $\mathrm{D}$-xylose as sole $\mathrm{C}$ sources and produce acids from inulin, lactose, and maltose. Acids are not produced from melibiose, meso-inositol, or D-mannitol by most strains. An alkaline reaction occurs with $\alpha$-ketoglutarate and succinate. Formate is not utilized. Starch and Tween 40 are not hydrolyzed. Nitrate is not reduced. Tyrosinase is not produced.

The $\mathrm{G}+\mathrm{C}$ contents of the DNAs are 70 to $72 \mathrm{~mol} \%$ (as determined by the $T_{m}$ method).

The type strain of $A$. fucosus subsp. fucosus is strain VKM Ac-1345.

The description given above was based on five strains.

Description of Agromyces fucosus subsp. hippuratus sp. nov., subsp. nov. Agromyces fucosus subsp. hippuratus (hip.pu.ra'tus. N.L. n. hippuratum, hippurate; N.L. adj. hippuratus, decomposes hippurate). Strains are distinguished from $A$. fucosus subsp. fucosus strains by the 
presence of xylose in whole-cell hydrolysates and by some physiological characteristics. Strains grow on media supplemented with melibiose, and no growth occurs when mesoinositol is the sole carbon source. Acids are not produced from lactose, maltose, raffinose, salicin, sucrose, and trehalose. Succinate is not utilized. Hippurate is hydrolyzed. Reduces nitrate and produces tyrosinase.

One strain utilizes $\alpha$-ketoglutarate and trans-aconitate and exhibits antibiotic activity against some gram-positive bacteria.

The $\mathrm{G}+\mathrm{C}$ content of the DNA is $72 \mathrm{~mol} \%$ (as determined by the $T_{m}$ method).

The type strain of $A$. fucosus subsp. hippuratus is strain VKM Ac-1352.

The description given above was based on two strains.

\section{REFERENCES}

1. Carlson, R. R., and A. K. Vidaver. 1982. Taxonomy of Corynebacterium plant pathogens, including a new pathogen of wheat, based on polyacrylamide gel electrophoresis of cellular proteins. Int. J. Syst. Bacteriol. 34:315-326.

2. Casida, L. E. 1986. Genus Agromyces, p. 1329-1331. In P. H. A. Sneath, N. S. Mair, M. E. Sharpe, and J. G. Holt (ed.), Bergey's manual of systematic bacteriology, vol. 2. The Williams \& Wilkins Co., Baltimore.

3. Collins, M. D. 1982. Lipid composition of Agromyces ramosus. FEMS Microbiol. Lett. 14:187-189.

4. Collins, M. D. 1985 . Isoprenoid quinone analysis in bacterial classification and identification, p. 267-287. In M. Goodfellow and D. E. Minnikin (ed.), Chemical methods in bacterial systematics. Academic Press, Inc. (London), Ltd., London.

5. Davis, M. J., A. G. Gillaspie, A. K. Vidaver, and R. W. Harris. 1984. Clavibacter: a new genus containing some phytopathogenic coryneform bacteria, including Clavibacter $x y l i$ subsp. $x y l i$ sp. nov., subsp. nov. and Clavibacter xyli subsp. cynodontis subsp. nov., pathogens that cause ratoon stunting disease of sugarcane and bermudagrass stunting disease. Int. J. Syst. Bacteriol. 34:107-117.

6. Dobritsa, S. V. 1985. Restriction analysis of the Frankia spp. genome. FEMS Microbiol. Lett. 29:123-128.

7. Eveleigh, D. 1983. Microbial monosaccharides and polysaccharides, p. 3-60. In A. I. Laskin and H. A. Lechevalier (ed.), Handbook of microbiology, vol. 4. CRC Press, Boca Raton, Fla.

8. Evtushenko, L. I., V. N. Akimov, S. V. Dobritsa, and S. D. Taptykova. 1989. A new species of actinomycete, Amycolata alni. Int. J. Syst. Bacteriol. 39:72-77.

9. Evtushenko, L. I., T. G. Dobrovolskaya, L. V. Lysak, N. F. Tchernyakovskaya, H. I. Zgurskaya, V. M. Adanin, and V. Y. Ilchenko. 1991. Actinomycetes with diaminobutyric acid in the cell wall isolated from soils. Mikrobiologiya 60:920-925. (In Russian.)

10. Gledhill, W. E., and L. E. Casida. 1969. Predominant catalasenegative soil bacteria. III. Agromyces gen. nov., microorgan- isms intermediary to Actinomyces and Nocardia. Appl. Microbiol. 18:340-349.

11. Goodfellow, M. 1971. Numerical taxonomy of some nocardioform bacteria. J. Gen. Microbiol. 69:33-80.

12. Goodfellow, M., and T. Cross. 1984. Classification, p. 7-164. In M. Goodfellow, M. Mordarski, and S. T. Williams (ed.), The biology of the actinomycetes. Academic Press, Inc. (London), Ltd., London.

13. Gordon, R. E., D. A. Barnett, J. E. Handerhan, and C. H.-N. Pang. 1974. Nocardia coeliaca, Nocardia autotrophica, and the nocardin strain. Int. J. Syst. Bacteriol. 24:54-63.

14. Hasegawa, T., M. Takisawa, and S. Tanida. 1983. A rapid analysis for chemical grouping of aerobic actinomycetes. J. Gen. Appl. Microbiol. 329:1319-1322.

15. Jones, D., J. Watkins, and D. J. Meyer. 1970. Cytochrome composition and effect of catalase on growth of Agromyces ramosus. Nature (London) 226:1249-1250.

16. Kovacs, N. 1956. Identification of Pseudomonas pyocyanea by the oxidase reaction. Nature (London) 178:703.

17. Maltsev, I. I., A. I. Kalinovskii, H. I. Zgurskaya, and L. I. Evtushenko. 1992. Tyvelose in Agromyces cell walls. Syst. Appl. Microbiol. 15:187-190.

18. Marmur, J., and P. Doty. 1962. Determination of the base composition of deoxyribonucleic acid from its thermal denaturation temperature. J. Mol. Biol. 5:109-118.

19. Meyer, S. A., and K. H. Schleifer. 1978. Deoxyribonucleic acid reassociation in the classification of coagulase-positive staphylococci. Arch. Microbiol. 117:183-188.

20. Minnikin, D. E., A. G. O'Donnel, M. Goodfellow, G. Alderson, M. Athalye, A. Shaal, and J. H. Parlett. 1984. An integrated procedure for the extraction of bacterial isoprenoid quinones and polar lipids. J. Microbiol. Methods 2:233-241.

21. Owen, R. J., and D. Pitcher. 1985. Current methods for estimating DNA base composition and levels of DNA-DNA hybridisation, p. 67-93. In M. Goodfellow and D. E. Minnikin (ed.), Chemical methods in bacterial systematics. Academic Press, Ltd., London.

22. Ozerskaya, S. M., and A. N. Vasilenko. 1992. Package for cluster analysis on an IBM PC computer. Binary 4:33-34.

23. Pridham, T. G., and D. Gottlieb. 1948. The utilization of carbon compounds by some Actinomycetales as an aid for species determination. J. Bacteriol. 56:107-114.

24. Schleifer, K. H., and O. Kandler. 1972. Peptidoglycan types of bacterial cell walls and their taxonomic implications. Bacteriol. Rev. 36:407-477.

25. Stackebrandt, E., B. Wunner-Füssl, V. J. Fowler, and K. H. Schleifer. 1981. Deoxyribonucleic acid homologies and ribosomal ribonucleic acid similarities among sporeforming members of the order Actinomycetales. Int. J. Syst. Bacteriol. 31:420-433.

26. Zgurskaya, H. I., L. I. Evtushenko, V. N. Akimov, J. M. Young, and L. V. Kalakoutskii. Rathayibacter gen. nov., including the species Rathayibacter graminicolus sp. nov., Rathayibacter rathayi comb. nov., Rathayibacter tritici comb. nov., and Rathayibacter iranicus comb. nov. Submitted for publication. 